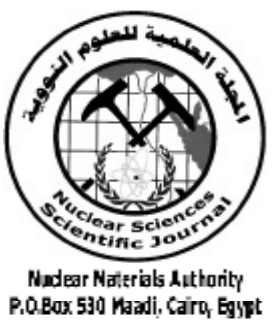

ISSN 2314-5609

Nuclear Sciences Scientific Journal

$6,55-70$

2017

http://www.ssnma.com

\title{
RADIOACTIVITY, MINERALOGY AND RARE EARTH ELEMENTS (REE) GEOCHEMISTRY OF MONZOGRANITES AND ALKALI-FELDSPAR GRANITES, WADI HAWASHIA, NORTH EASTERN DESERT, EGYPT
}

\author{
MOHAMED O. EL-HUSSEINY \\ Nuclear Materials Authority, P. O. Box 530 El Maadi, Cairo, Egypt
}

\begin{abstract}
The studied monzogranites and alkali-feldspar granites of W. Hawashia, North Eastern Desert of Egypt occur as small granitic mass intruding the granodiorites. The monzogranites represent the central part of the mapped area and are intruded by the alkali-feldspar granites forming a small mass or cupola at the roof of the monzogranites. The alkali-feldspar granites cut by faults trending in NNW-SSE, E-W and NNE-SSW directions and show brecciation and local silicification, hematitization, sericitization and chloritization.

Petrographically, the monzogranites are essentially composed of plagioclase, quartz, alkali-feldspars and biotite. The accessory minerals are apatite and zircon. The alkali-feldspar granites are mainly composed of K-feldspars, quartz, albite and biotite, while zircon, allanite, samarskite and violet fluorite are the accessory minerals.

Chondrite-normalized REE patterns show that the alkali-feldspar granites have higher REE content $\left(\sum \mathrm{REE}=202 \mathrm{ppm}\right)$ than the monzogranites $\left(\sum \mathrm{REE}=43 \mathrm{ppm}\right)$. The monzogranites have small negative Eu anomaly reflecting high contents of plagioclase, while the alkali-feldspar granites show large negative $\mathrm{Eu}$ anomaly suggesting highly fractionated magma characterized by the least content of plagioclase.

The chemical analyses of uranium and thorium indicate that the examined alkali-feldspar granites are characterized by higher $U$ and Th contents (averages are 73 and $119 \mathrm{ppm}$, respectively) compared with the studied monzogranites (averages are 9 and $21 \mathrm{ppm}$, respectively). Detailed microscopic investigations supported by X-ray diffraction (XRD) and Environmental Scanning Electron Microscope (ESEM) with EDX microanalyzer for the radioactive alkali-feldspar granite samples revealed the presence of uranophane as secondary uranium mineral and thorite as thorium mineral beside some U-bearing accessory minerals such as samarskite, allanite, metamict zircon and violet fluorite.
\end{abstract}

\section{INTRODUCTION}

The younger granites are widely distributed allover the Egyptian Shield, constituting approximately $30 \%$ of its plutonic assemblage. The younger granites were classified as Gattarian granites (Hume, 1935), younger intrusive red and pink granites (El-Ramly and Akaad, 1960), late-, to post-orogenic granites (ElGaby, 1975) and G-II to G-III granites (Hussein et al., 1982). They were emplaced between
530 and $620 \mathrm{Ma}$ (Hassan and Hashad, 1990, Moussa et al., 2008) that is a range contemporaneous with the Pan-African tectonic thermal event as defined by Kennedy (1964). Most of the post-tectonic younger granites are $\mathrm{K}$-and LILE enriched, calc-alkaline to mildly alkaline rocks with I-type affinity. A part of the younger granites has been classified as A-type granites (Whalen et al., 1987).

The Egyptian younger granites are fa- 
vourable host rocks for U-mineralization in many parts of the Eastern Desert and Sinai, e.g. Gabal Gattar (Shalaby, 1995; El-Kammar et al., 2001; Shalaby et al., 2010 and El Kholy et al., 2012), Gabal El Missikat (Abu Deif et al., 2007 \& Abu Deif and El-Tahir, 2008), Gabal Um Ara (Abdalla, 1996 \& Dawood and Abd El-Naby, 2001)

Several authors previously studied W. Hawashia area e.g. Mohamed et al.(1994) stated that the Hawashia complex comprises calc-alkaline granitic rocks of peraluminous character. The bulk of the complex is composed of biotite granites, while the other intrusive phases namely the leucocratic- and alkali-feldspar granites, only constitute a minor proportion of the exposed surface area of the complex. Numerous pegmatitic veins and pods are scattered within the alkali-feldspar granites. Fractional crystallization is the dominant mechanism, being necessary to explain the chemical attributes within the complex. The alkali-feldspar granites and related pegmatitic veins represent the final stage of this calc-alkaline suite. Moussa (1998) studied North W. Hawashia granitic rocks and concluded that the Hawashia granites are subsolvus granites originated from calc-alkaline magma enriched in $\mathrm{Rb}$ relative to $\mathrm{Sr}$ and $\mathrm{Ba}$ indicating alkaline affinity and were emplaced in a within plate tectonic setting. Also, he reported that the age of Hawashia younger granites is 556Ma. Abu Zeid (2006) classified the younger granitic rocks of Hawashia area into alkali-feldspar granites and monzogranites, while the pegmatitic rocks are concentrated in the alkali-feldspar granites as circular and elongated bodies with variable dimensions.

It is obvious that all the previous studies carried on the younger granitic rocks under consideration focused on the geology, geochemistry and age dating. The present work deals with the mineralogy and REE geochemistry of the studied monzogranites and alkali-feldspar granites as well as their radioactive and accessory minerals as the main carriers of radioactivity.

\section{GEOLOGIC SETTING}

The examined granites are located about 10 $\mathrm{Km}$ north Wadi Hawashia. The area is bounded by Lat. $28^{\circ} 20^{\prime}$ and $28^{\circ} 25^{\prime} \mathrm{N}$ and Long. $32^{\circ} 24^{\prime}$ and $32^{\circ} 30^{\prime} \mathrm{E}$. The area is covered by older and younger granitoids of moderate high elevations and gentle slopes (Fig. 1). It is bounded by wide Wadis such as Wadi Hawashia extending NE-SW with the maximum width about $300 \mathrm{~m}$ and becoming narrower at its southern parts reaching about $50 \mathrm{~m}$ (Abu Zeid, 2006). The older granitoids represent the most common rock in the area, covering about $90 \%$ of the mapped area. They occur as low hills of moderate elevations. They are medium to coarse grained, hard, massive and gray in color. The younger granites occur as small mass in the central part of the studied area intruding the older granitoids. They have light colors ranging from whitish (monzogranites) to pink (alkali-feldspar granites). They are medium- to coarse-grained, hard, massive and sometimes show exfoliation and cavernous weathering. Many pegmatitic veins and pods are hosted in the alkali-feldspar granites with different shapes and sizes. The monzogranites are intruded by the alkalifeldspar granites which form small mass or cupola at the roof of the pluton (Mohamed et al., 1994). The younger granites contain red jasperoid veins stained by iron oxides and occur as fracture filling.

The alkali-feldspar granites are bounded and cut by faults having NNW-SSE, NNESSW and E-W directions causing the shearing of the study granites which show brecciation and local silicification, hematitization, sericitization and chloritization.

\section{PETROGRAPHIC FEATURES}

The modal compositions of 10 representative samples of the studied younger granites are given in Table (1). The rock names are assigned according to Streckeisen (1976). The granitic samples fall in both the alkalifeldspar granites and monzogranites fields (Fig.2). 


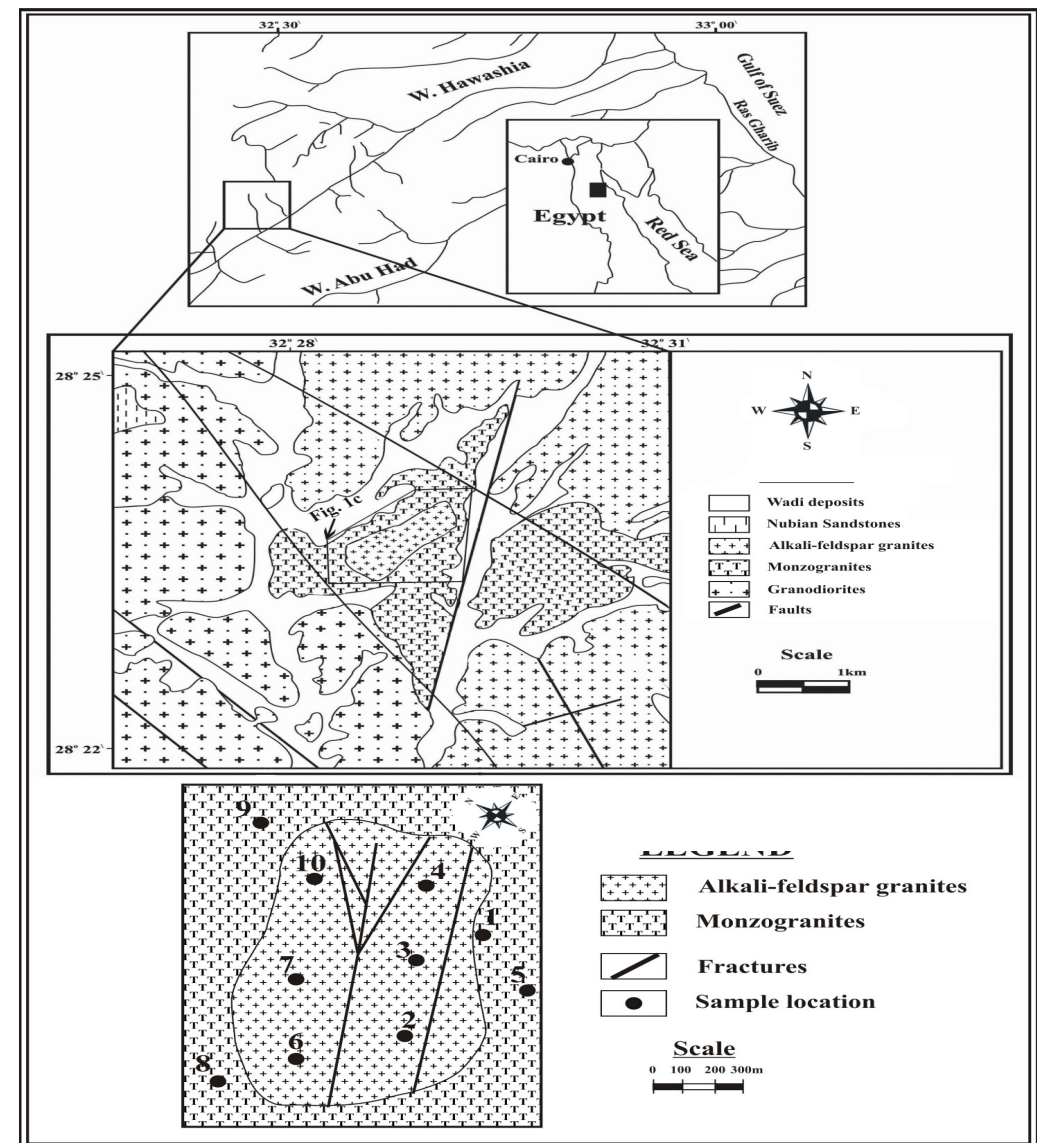

Fig. 1: a-Location of Wadi Hawashia, b- Geological map of Wadi Hawashia area, c-Geological sketch map of the studied granites (After Mohamed et al., 1994)

Table 1 : Modal composition of the studied younger granites

\begin{tabular}{|c|c|c|c|c|c|c|}
\hline S. No. & Quartz & $\begin{array}{r}\text { K- } \\
\text { feldspars }\end{array}$ & Plagioclases & Biotite & Accessories & Opaques \\
\hline \multicolumn{7}{|c|}{ Monzogranites } \\
\hline $\mathbf{1}$ & 33 & 24 & 36 & 5 & 0.0 & $\mathbf{1}$ \\
\hline 5 & 35 & 26 & 35 & 3 & 0.5 & 0.5 \\
\hline 8 & 34 & 24 & 34 & 6 & 0.0 & $\mathbf{1}$ \\
\hline 9 & 32 & 23 & 37 & 7 & 0.5 & 0.5 \\
\hline Average & 33.5 & 24.3 & 35.5 & 5.3 & 0.25 & 0.75 \\
\hline \multicolumn{7}{|c|}{ Alkali-feldspar granites } \\
\hline 2 & 37 & 55 & 4 & 3 & 0.5 & 0.5 \\
\hline 3 & 35 & 57 & 5 & 2 & 0.5 & 0.5 \\
\hline 4 & 34 & 56 & 6 & 4 & 1 & 0.0 \\
\hline 6 & 36 & 54 & 7 & 2 & 0.5 & 0.5 \\
\hline 7 & 33 & 58 & 3 & 4 & 1 & 0.75 \\
\hline 10 & 38 & 55 & 2 & 3 & $\mathbf{1}$ & $\mathbf{1}$ \\
\hline Average & 35.5 & 55.8 & 4.5 & 3 & 0.75 & 0.5 \\
\hline
\end{tabular}




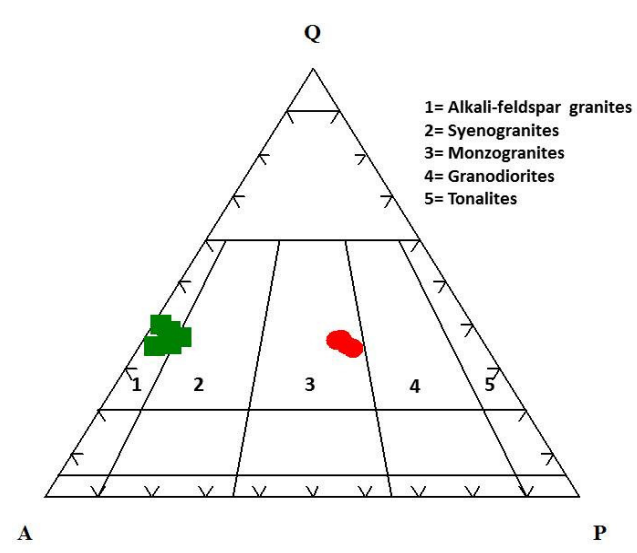

Fig. 2: QAP diagram of the studied younger granites (According to Streckeisen, 1976)

\section{Monzogranites}

They are mainly composed of plagioclases, quartz, K-feldspars and biotite. The accessory minerals are zircon, apatite and opaques. The secondary minerals are sericite, muscovite, hematite and chlorite.

Plagioclases $\left(\mathrm{An}_{20-27}\right)$ occur as subhedral to euhedral medium to coarse tabular crystals showing albite and carlsbad twinnings. Some crystals show partial to complete saussuritization (Fig. 3). Zoned plagioclases occur associating to biotite and hornblende. Lamellae of plagioclase crystals show cracking and stretching due to strain.

Quartz is present as medium to coarse grains ranging in size from $0.2 \mathrm{~mm}$ up to $3 \mathrm{~mm}$. It shows undulose extinction and cracking. Sometimes occur as thin veinlets among the other minerals. Some crystals contain inclusions of biotite and zircon.

Minor amounts of K-feldspars occur as subhedral to euhedral crystals of string and patchy perthite types. Some crystals show sericitization. Sometimes, small laths of albite occur as reaction rims between two perthite crystals indicating $\mathrm{Na}$ metasomatism. Some crystals show cracking, fracturing and granulation due to strain.
Biotite shows euhedral to subhedral flakes with pale brown color having strong pleochroism from pale brown to dark brown. Often, it is slightly altered to green chlorite with radiating bands or patches. Occasionally, biotite flakes are coated with opaques. Also, it contains minute crystals of zircons surrounded by pleochroic haloes indicating radioactive effect.

Zircon occurs as small prismatic crystals of yellow color associated with biotite. Apatite occurs as rod-like crystals with various sizes as inclusions in biotite and plagioclases (Fig. 4).

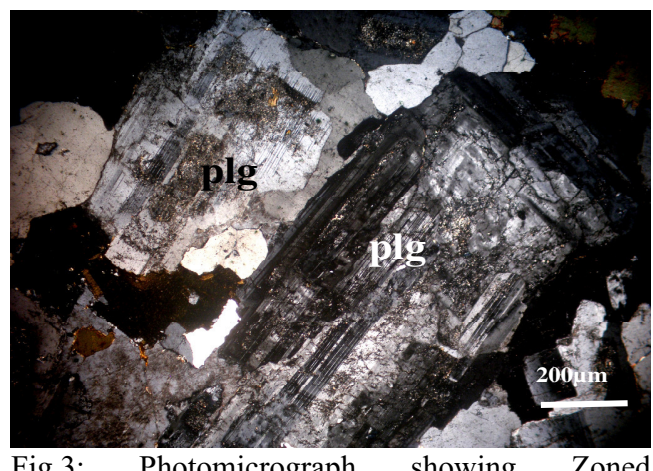

Fig.3: Photomicrograph showing Zoned plagioclase (plg.) shows partially saussuritization, monzogranite, XPL

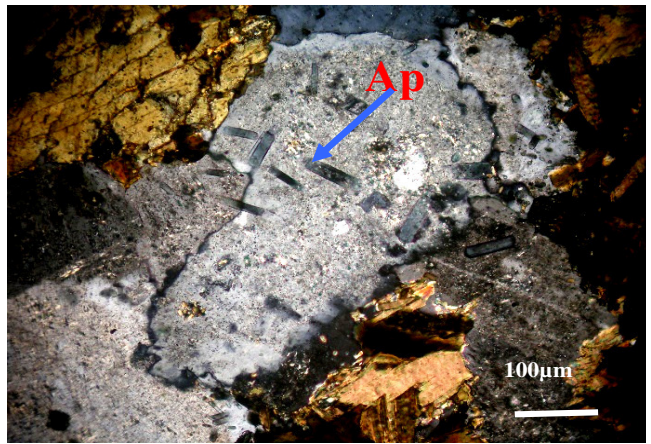

Fig.4: Photomicrograph showing Apatite (Ap) enclosed in plagioclase, monzogranite, XPL 


\section{Alkali-Feldspar Granites}

These rocks are mainly composed of Kfeldspars, quartz, minor plagioclase and biotite. The main accessory minerals are zircon, allanite, apatite, violet fluorite and samarskite.

K-feldspars occur as subhedral to euhedral crystals of microcline and orthoclase perthites. Orthoclase perthite occurs as patchy and string types. Microcline perthite is of patchy type. Phenocrysts of perthite are occasionally penetrated by veinlets of quartz. Some crystals show cracking and dislocation due to strain.

Quartz grains have two sizes; the big size shows wavy extinction and is mostly cracked. The second type is less than $0.3 \mathrm{~mm}$ in size and presents as thin veinlets between the other minerals.

Plagioclase $\left(\mathrm{An}_{2-10}\right)$ shows rectangular to subhedral plates of $2 \mathrm{~mm}$ or less with variable degrees of sussuritization. It shows albitic twinning. Some crystals show kinked lamellae.

Biotite occurs as subhedral flakes of light brown color characterized by pleochroism from light brown to dark brown. It contains some euhedral crystals of zircon (Fig.5). Some biotite crystals are completely altered to chlorite and enclose minute crystals of zoned zircon surrounded by pleochroic haloes due to radioactive effect.

Allanite occurs as euhedral to subhedral prismatic crystals of brown color associating biotite.

Zircon is present as short euhedral prisms of high relief and pale brown color. It is partially metamectized with obvious clouded colors, mostly yellow to grey, due to wide spreading of the radioelements. Also, it is zoned and fractured exhibiting radial fractures.

Uranophane occurs as aggregate crystals associating iron oxides, quartz, K-feldspars and plagioclase (Fig. 6).

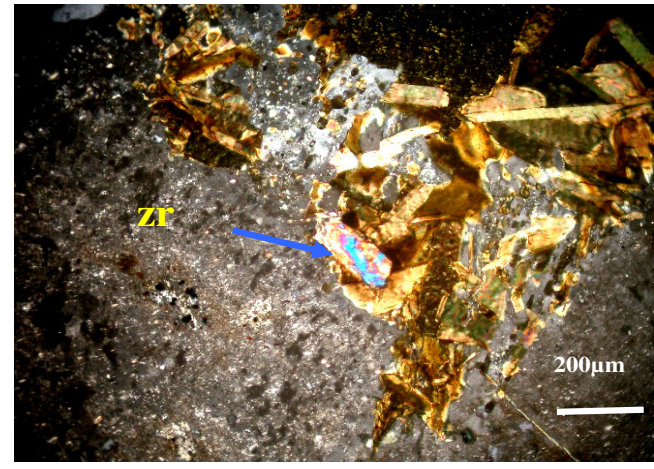

Fig.5: Photomicrograph showing Euhedral crystal of zircon (Zr) associated biotite, alkali-feldspar granite, XPL

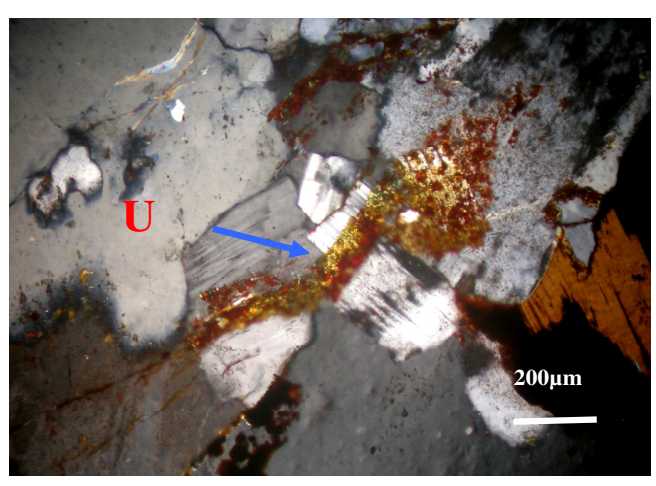

Fig.6: Photomicrograph showing Uranophane (U) associated iron oxides, quartz, perthite and plagioclase, alkali-feldspar granite, XPL

\section{METHODOLOGY}

Thin sections were prepared and examined to decipher the texture, mineralogy, alteration and deformation using a polarizing microscope. The samples are crushed to separate the different minerals using heavy liquid bromoform (specific gravity $=2.85 \mathrm{gm} / \mathrm{cm}^{3}$ ). Then, the different minerals in the heavy fractions are picked using the binocular microscope. The heavy minerals are analyzed by X-ray diffraction (XRD) using unit Philips PW-3710 with generator PW-1830, Cu target tube and Ni filter at $40 \mathrm{Kv}$ and $30 \mathrm{~mA}$. The 
semi-quantitative analysis of the radioactive minerals is done using the Environmental Scanning Electron Microscope (ESEM) model (Philips XL30) supported by energy dispersive spectrometer (EDS) unit equipped in the main laboratories of the War Chemicals, Ministry of Defense. The analytical conditions are 25$30 \mathrm{Kv}$ accelerating voltage, 1-2micron beam diameter and 60-120 second counting time. The chemical analyses of the rare earth elements (REEs) for 10 samples are carried out by the Inductively Coupled Plasma Optical Emission Spectrometry (ICP-OES). All the previous analyses carried out at Labs of the Nuclear Materials Authority (NMA). Chemical analyses of $U$ and Th of 10 samples (4 samples are monzogranites and 6 samples are alkali-feldspar granites) are carried out by the Inductively Coupled Plasma Optical Emission Spectrometry (ICP-OES) at Labs of the Egyptian Atomic Energy Authority.

\section{GEOCHEMISTRY OF RARE EARTH ELEMENTS (REE)}

Ten representative samples (4 samples from the studied monzogranites and 6 samples from the studied alkali-feldspar granites) were analyzed for REEs and the results are shown in
Table (2) which clears that the alkali-feldspar granites have higher REE contents than the monzogranites. The average of total REE in the alkali-feldspar granites is $202 \mathrm{ppm}$ while, their content in the monzogranites is $43 \mathrm{ppm}$. The depletion of REE in the studied monzogranites is mainly attributed to various processes including fractionation of monazite during partial melting of the crust, magmatic differentiation (Cuney and Friedrich 1987), hydrothermal leaching (Cathelineau, 1987) and a combination of hydrothermal leaching and magmatic differentiation.

The REE pattern of the studied monzogranites (Fig. 7) shows very small REE fractionation where $(\mathrm{La} / \mathrm{Lu}) \mathrm{n}$ vary from 0.48 to 0.72 with an average of 0.59 , semi-flat HREE (Gd/ $\mathrm{Lu}) \mathrm{n}$ vary from 0.66 to 0.87 with an average of 0.80 , with small negative Eu-anomaly $(\mathrm{Eu} /$ $\left.\mathrm{Eu}^{*}\right)=0.53-0.73$ with an average of 0.61 .

The average of total REE in the alkalifeldspar granites is $202 \mathrm{ppm}$. The elevated REE content compared with the studied monzogranites may be due to the presence of REE-bearing accessory minerals such as zircon, allanite and apatite (Banks et al., 1994). They have small fractionated REE pattern (Fig. 8) where the average of $(\mathrm{La} / \mathrm{Lu}) \mathrm{n}=1.82$.

Table 2: Chemical analysis data of REEs (ppm) of the studied younger granites

\begin{tabular}{|c|c|c|c|c|c|c|c|c|c|c|c|c|}
\hline \multirow[t]{2}{*}{ S. No. } & \multicolumn{4}{|c|}{ Monzogranites } & \multirow[t]{2}{*}{ Av. } & \multirow[b]{2}{*}{2} & \multirow[b]{2}{*}{3} & \multicolumn{4}{|c|}{ Alkali-feldspar granites } & \multirow[t]{2}{*}{ Av. } \\
\hline & 1 & 5 & 8 & 9 & & & & 4 & 6 & 7 & 10 & \\
\hline $\mathbf{L a}$ & 2.59 & 4.10 & 3.62 & 2.93 & 3.31 & 20.87 & 38.95 & 22.48 & 19.69 & 20.57 & 21.67 & 24.04 \\
\hline $\mathrm{Ce}$ & 5.95 & 10.87 & 9.91 & 7.94 & 8.67 & 53.04 & 76.3 & 51.89 & 46.37 & 55.65 & 52.3 & 55.93 \\
\hline Pr & 0.95 & 1.66 & 1.55 & 1.13 & 1.32 & 7.76 & 10.20 & 8.39 & 6.82 & 8.12 & 7.73 & 8.17 \\
\hline Nd & 5.25 & 8.87 & 8.16 & 5.90 & 7.05 & 38.33 & 47.33 & 40.87 & 38.30 & 43.15 & 41.15 & 41.52 \\
\hline Sm & 1.89 & 3.00 & 2.94 & 2.06 & 2.47 & 11.59 & 12.73 & 12.69 & 9.39 & 12.24 & 12.35 & 11.83 \\
\hline $\mathbf{E u}$ & 0.45 & 0.85 & 0.65 & 0.52 & 0.62 & 0.58 & 0.30 & 0.24 & 0.51 & 0.19 & 0.53 & 0.39 \\
\hline Gd & 3.48 & 4.17 & 3.95 & 3.37 & 3.74 & 13.38 & 18.89 & 16.48 & 15.06 & 13.21 & 11.55 & 14.76 \\
\hline Tb & 0.75 & 0.82 & 0.75 & 0.73 & 0.76 & 2.5 & 2.03 & 2.18 & 3.47 & 2.70 & 2.28 & 2.53 \\
\hline Dy & 4.85 & 5.59 & 5.15 & 5.20 & 5.20 & 16.14 & 15.45 & 16.58 & 19.17 & 15.41 & 13.80 & 16.09 \\
\hline Но & 1.10 & 1.26 & 1.18 & 1.21 & 1.19 & 3.33 & 2.78 & 3.36 & 3.8 & 3.12 & 3.22 & 3.27 \\
\hline Er & 3.15 & 3.69 & 3.64 & 3.68 & 3.54 & 8.14 & 10.17 & 8.72 & 11.07 & 9.55 & 9.73 & 9.56 \\
\hline Tm & 0.48 & 0.55 & 0.56 & 0.57 & 0.54 & 1.28 & 1.47 & 1.38 & 1.78 & 1.15 & 1.45 & 1.42 \\
\hline Yb & 3.34 & 3.86 & 3.95 & 3.97 & 3.78 & 8.58 & 10.49 & 12.45 & 12.22 & 8.34 & 9.47 & 10.26 \\
\hline Lu & 0.50 & 0.59 & 0.61 & 0.63 & 0.58 & 1.54 & 1.65 & 1.37 & 1.51 & 0.99 & 1.20 & 1.38 \\
\hline$\sum$ REE & 34.73 & 49.79 & 46.62 & 39.84 & 42.76 & 187.06 & 248.78 & 191.08 & 189.14 & 206.63 & 188.43 & 201.85 \\
\hline$\sum$ LREE & 17.08 & 29.35 & 26.83 & 20.48 & 23.44 & 132.17 & 173.12 & 136.56 & 121.08 & 139.92 & 135.73 & 139.76 \\
\hline$\sum$ HREE & 17.65 & 20.44 & 19.79 & 19.36 & 19.31 & 54.89 & 75.66 & 54.52 & 68.06 & 66.71 & 52.7 & 62.09 \\
\hline$(\mathbf{L a} / \mathbf{L u}) \mathbf{n}$ & 0.54 & 0.72 & 0.61 & 0.48 & 0.59 & 1.4 & 2.44 & 1.70 & 1.35 & 2.15 & 1.87 & 1.82 \\
\hline$(\mathbf{L a} / \mathbf{S m}) n$ & 0.86 & 0.86 & 0.77 & 0.89 & 0.85 & 1.13 & 1.92 & 1.11 & 1.31 & 1.05 & 1.10 & 1.27 \\
\hline (Gd/Lu)n & 0.86 & 0.87 & 0.80 & 0.66 & 0.80 & 1.07 & 1.42 & 1.49 & 1.23 & 1.65 & 1.19 & 1.34 \\
\hline $\mathbf{E u} / \mathbf{E u} *$ & 0.53 & 0.73 & 0.58 & 0.60 & 0.61 & 0.05 & 0.02 & 0.02 & 0.04 & 0.02 & 0.04 & 0.03 \\
\hline
\end{tabular}




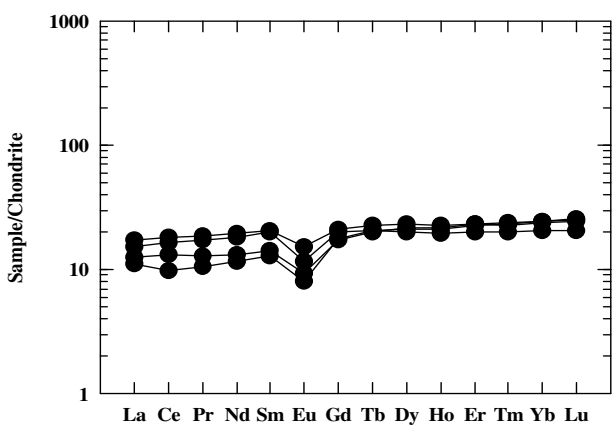

Fig.7: Chondrite REE pattern of the studied monzogranites

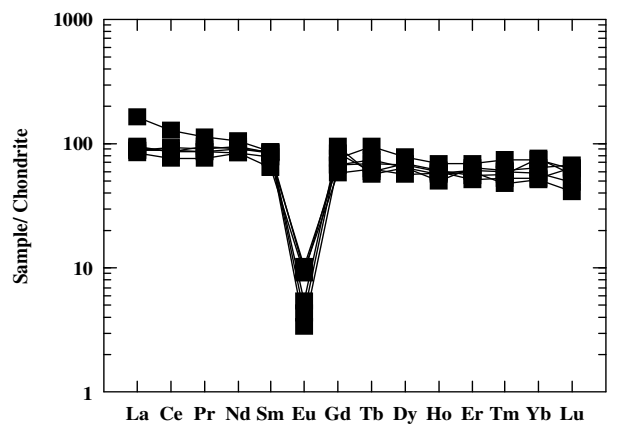

Fig. 8: Chondrite REE pattern of the studied alkalifeldspar granites

Also, they have enrichment of LREE where the average of $\sum$ LREE $=140 \mathrm{ppm}$ compared with the average of $\sum$ HREE $=62 \mathrm{ppm}$. The contribution of the LREE bearing accessory minerals such as monazite, apatite and allanite represents potential contribution to the LREE concentration (Miller and Mittlefehldt 1982). This is confirmed by the petrographic study which shows the alkali-feldspar granites contain allanite and apatite as accessory minerals.

Figure (9) shows the average of chondrite normalized REE patterns of the studied monzogranites and alkali-feldspar granites. The diagram clarifies that the alkali-feldspar granites have higher contents of REE than monzo-

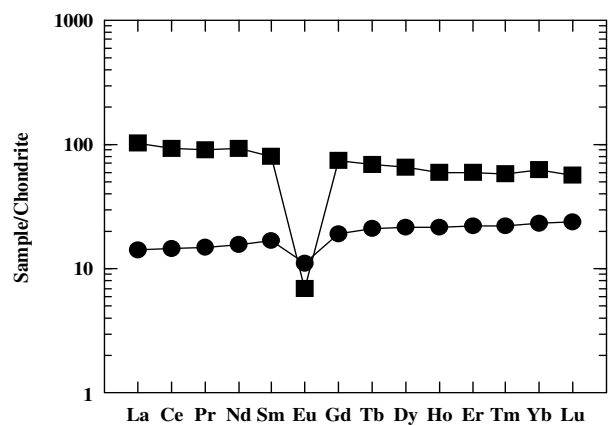

Fig.9: Average chondrite normalized pattern of the studied granites

granites. Also, the monzogranites have small negative Eu-anomaly while, alkali-feldspar granites have large negative Eu-anomaly indicating the studied alkali-feldspar granites formed from highly fractionated magma characterized by the presence of the least content of plagioclase (Singh et al., 2006).

\section{RADIOACTIVITY}

Uranium and thorium have relatively low concentration in magma if compared with other elements. Their concentration increases in the late stages of differentiation, where they form their own minerals or occur as traces incorporated in other minerals of both the late magmatic and hydrothermal stages.

Ten representative samples (4 samples represent the monzogranites and 6 samples) represent the alkali-feldspar granites are selected for the chemical measurements of $\mathrm{U}$ and Th. The samples are analyzed by the Inductively Coupled Plasma-Optical Emission Spectrometer (ICP/OES) at the Labs of the Egyptian Atomic Energy Authority. The results are shown in Table (3).

Table (3) shows that monzogranites contain $U$ ranging from 6 to $15 \mathrm{ppm}$ with an average of $9 \mathrm{ppm}$ and Th content varies from 17 to $25 \mathrm{ppm}$ with an average of $21 \mathrm{ppm}$. Th/U ratio ranges from 1.33 to 3.14 with an average 
of 2.6. Alkali-feldspar granites are higher than the monzogranites where the averages of $U$ and $T h$ are 73 and 119 ppm respectively. The average of $\mathrm{Th} / \mathrm{U}$ ratio is 1.66 , indicating enrichment with uranium.

Uraniferous granite is the granite which contains uranium at least twice the Clark value (4 ppm) for the normal granite (Darnely, 1982; Shalaby, 1995; Assaf et al., 1997 and Ahmed and Dardier, 1999). Accordingly, the studied younger granites (both monzogranites and alkali-feldspar granites) are considered as uraniferous granites.

\section{MINERALOGICAL STUDY}

Detailed microscopic investigations supported by X-ray diffraction (XRD) and EDX analyses are used for the identification of the radioactive minerals. These mineralogical studies confirmed the presence of thorite and secondary uranium minerals as uranophane in addition to $U$ and $T h$ bearing minerals represented by samarskite, metamict zircon, allanite, and violet fluorite.

Table 3: Chemical analysis of $U$ and Th of the studied younger granites

\begin{tabular}{lrrrrrr|rrrrrr}
\hline \multicolumn{1}{c}{ Monzogranites } & Av. & \multicolumn{1}{c}{ Alkali-feldspar granites } & Av. \\
S. No. & 1 & 5 & 8 & 9 & & 2 & 3 & 4 & 6 & 7 & 10 & \\
\hline Th & 25 & 22 & 17 & 20 & 21 & 140 & 124 & 97 & 115 & 135 & 103 & 119 \\
U & 8 & 7 & 6 & 15 & 9 & 83 & 60 & 58 & 70 & 95 & 69 & 72.5 \\
Th/U & 3.13 & 3.14 & 2.83 & 1.33 & 2.61 & 1.69 & 2.07 & 1.67 & 1.64 & 1.42 & 1.49 & 1.66 \\
\hline
\end{tabular}

\section{Thorite ( $\left.\mathrm{Th} \mathrm{SiO}_{4}\right)$}

Thorite is rare nesosilicate of thorium, crystallizes in the tetragonal system and is isomorphous with zircon. It is the most common mineral of thorium. Thorite is commonly metamict and hydrated making it optically isotropic and amorphous. Owing to differences in composition, the specific gravity varies from 4.4 to $6.6 \mathrm{gm} / \mathrm{cm}^{3}$. Hardness is 4.5 and the luster is vitreous or resinous. The color is normally black, but also brownish black, orange, yellowish orange and dark green. The studied thorite occurs as subhedral to euhedral black crystals associated with quartz, K-feldspars and biotite. Thorite is isomorphic with zircon and it is evident that a large part of thorium is incorporated in the zircon structure (Rankama and Sahama, 1955). EDX analysis shows that thorite is mainly composed of $\mathrm{ThO}_{2}, \mathrm{SiO}_{2}$, $\mathrm{UO}_{2}$ in addition to $\mathrm{Y}$ and $\mathrm{Fe}$ (Fig. 10). It is confirmed by the XRD analysis (Table 4).

\section{Uranophane Ca $\left(\mathrm{UO}_{2}\right)_{2}\left(\mathrm{SiO}_{3} \mathrm{OH}\right)_{2} 5 \mathrm{H}_{2} \mathrm{O}$}

Uranophane is one of the most common secondary uranium minerals. It represents the most abundant and widely distributed of various uranium silicate. It is composed of a hydrated $\mathrm{Ca}$ and $\mathrm{U}$ silicates and appears to be of supergene origin in the oxide zones of most uranium deposits (Cesbron, 1993). The studied uranophane occurs as lemon yellow soft

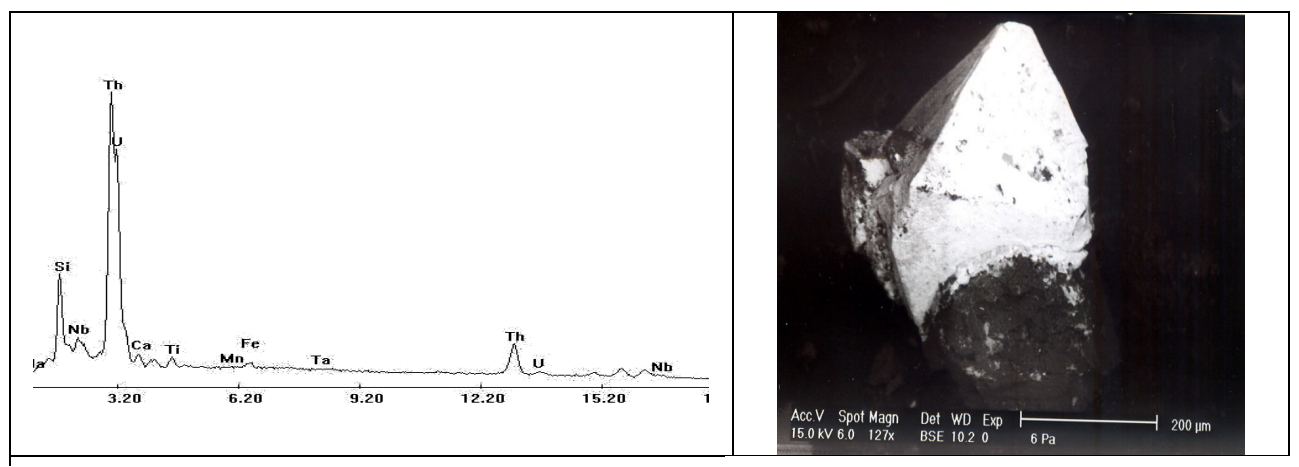

Fig.10: EDX and BSE image of thorite 
Table 4: XRD data of some radioactive minerals of the alkali-feldspar granites

\begin{tabular}{|c|c|c|c|}
\hline \multirow{2}{*}{$\begin{array}{l}\text { Sample } \\
\mathbf{d A}^{-}\end{array}$} & \multirow[b]{2}{*}{$\overline{\mathbf{I}} \overline{\mathbf{I}}^{-}$} & \multicolumn{2}{|c|}{$\begin{array}{r}\text { Samarskite (10- } \\
\text { 398) }\end{array}$} \\
\hline & & $\mathrm{dA}^{--}$ & I/Io- \\
\hline 4.08 & 2 & 4.03 & 20 \\
\hline 3.25 & 19 & 3.23 & 30 \\
\hline 3.14 & 17 & 3.13 & 40 \\
\hline 3.00 & 100 & 2.98 & 100 \\
\hline 2.95 & 33 & 2.92 & 90 \\
\hline 2.60 & 22 & 2.59 & 6 \\
\hline 2.08 & 2 & 2.07 & 4 \\
\hline 1.83 & 28 & 1.83 & 20 \\
\hline 1.65 & 3 & 1.65 & 6 \\
\hline 1.56 & 23 & 1.561 & 30 \\
\hline 1.50 & 6 & 1.50 & 6 \\
\hline \multicolumn{2}{|l|}{ Sample } & \multicolumn{2}{|c|}{ Thorite (11-o419) } \\
\hline $\mathbf{d}^{-5}$ & $\overline{\mathbf{I}} \mathbf{1}^{-}$ & $\mathbf{d}^{-}$ & I/ \\
\hline 4.72 & 11 & 4.72 & 85 \\
\hline 3.56 & 19 & 3.55 & 100 \\
\hline 2.67 & 7 & 2.676 & 75 \\
\hline 2.36 & 5 & 2.361 & 5 \\
\hline 2.22 & 5 & 2.222 & 30 \\
\hline 2.00 & 3 & 2.019 & 20 \\
\hline 1.89 & 6 & 1.885 & 30 \\
\hline 1.83 & 10 & 1.834 & 65 \\
\hline
\end{tabular}

aggregates crystals (Fig. 11). It occurs as fissure filling or fibers coating quartz grains or altered K-feldspars. EDX analysis shows that uranophane is essentially composed of $\mathrm{UO}_{2}$, $\mathrm{SiO}_{2}$ and $\mathrm{CaO}$ (Fig. 12).

\section{Samarskite}

Samarskite represents a group of minerals with chemical formula $\mathrm{ABO}_{4}$ where $\mathrm{A}=\mathrm{Y}, \mathrm{Ca}, \mathrm{Fe}, \mathrm{U}, \mathrm{Th}, \mathrm{REE}$ and $\mathrm{B}=\mathrm{Nb}$, Ta and Ti. They are chemically complex, usually completely metamict and completely altered. The chemical formula is ( $\mathrm{Y}, \mathrm{Ca}, \mathrm{U}, \mathrm{Fe}, \mathrm{REE})$ $(\mathrm{Nb}, \mathrm{Ta}, \mathrm{Ti}) \mathrm{O}_{4}$. The color of the examined samarskite is velvet black to dark brown (Fig. 13). The difference between samarskite-Y, ishikawaite and calciosamarskite is in the oc- cupation of the A-site, where samarskite-Y is dominated by $\mathrm{Y}+\mathrm{REE}$, whereas the A-site of ishikawaite is mainly $\mathrm{U}+\mathrm{Th}$ and $\mathrm{Ca}$ for calciosamarskite (Hanson et al., 1999). The EDX analysis of the separated samarskite grains

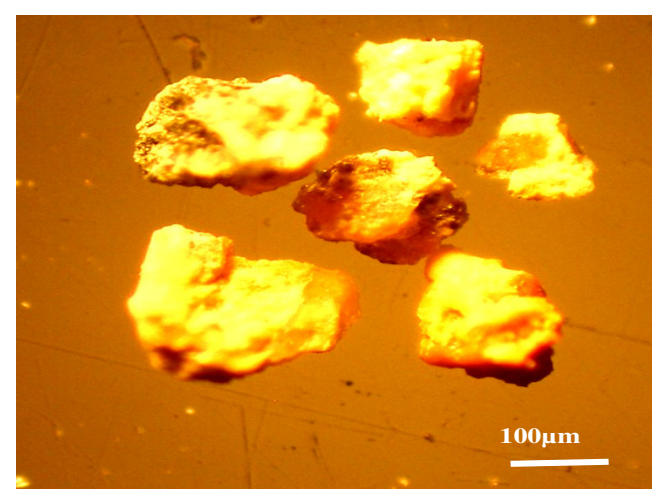

Fig.11: Stereophotograph showing lemon yellow uranophane grains
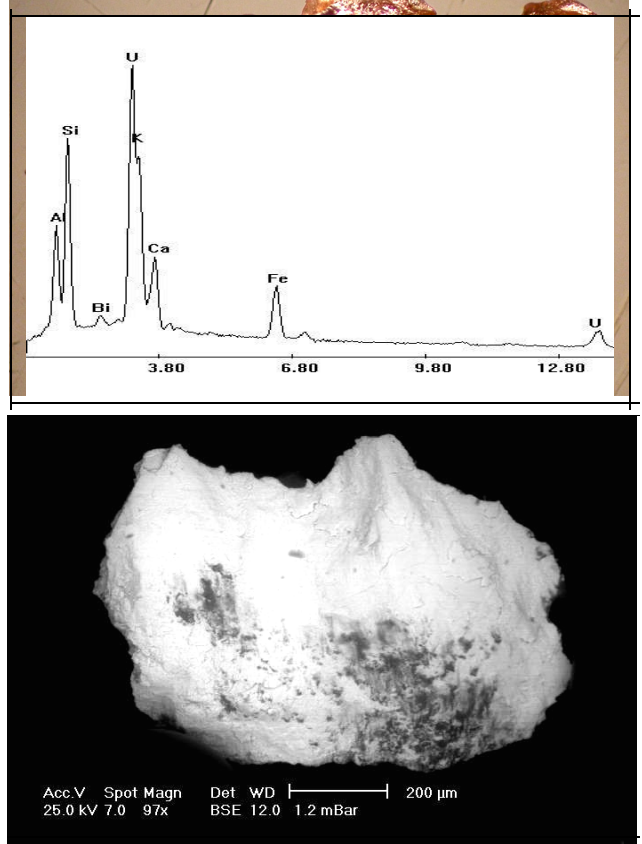

Fig.12: EDX and BSE image of uranophane 


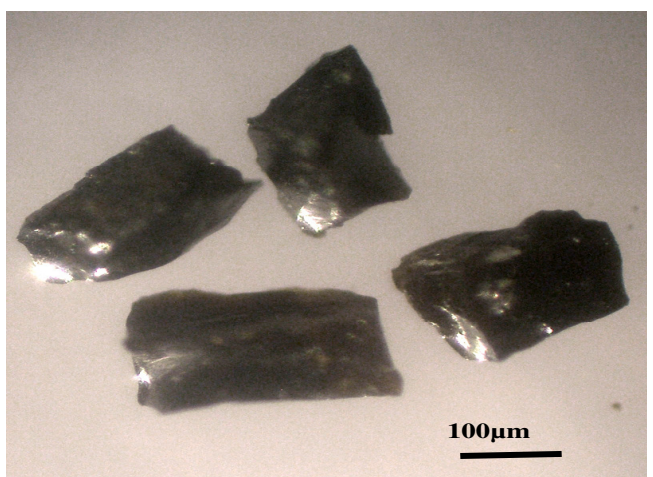

Fig.13: Stereophotograph showing black grains of samarskite

clears that it is mainly composed of $\mathrm{Nb}, \mathrm{Ca}$, $\mathrm{Ta}, \mathrm{Th}, \mathrm{Fe}$ and $\mathrm{U}$ with appreciable amounts of $\mathrm{Y}, \mathrm{Ti}, \mathrm{Na}$ with traces of $\mathrm{Ce}$ (Table, 5) and (Fig. 14). Samarskite is confirmed by the XRD (Table, 4).

\section{Zircon}

Zircon is one of the main accessory minerals in the A-type granite, crystallizing from the magmatic stage to the hydrothermal stage (Lei et al. 2005). Trace elements abundances (e.g. Hf, U, Th and Y) in zircon are very sensitive to the crystallization environments (Hoskin and Schaltegger, 2003). Zircon is isostructural with thorite $\left(\mathrm{ThSiO}_{4}\right)$ and coffinite $\left(\mathrm{USiO}_{4}\right)$, and is an important host for actinides such as $\mathrm{U}$ and $\mathrm{Th}$ in the continental crust and has been proposed as an immobilization phase for actinides (Förster, 2006). It is characterized by high durability to weathering, alteration, metamorphism and resistance to high-temperature diffusive re-equilibration. The studied zircon occurs as pale to deep brown euhedral prismatic crystals of translucent to opaque with dull luster (Fig. 15). However, some zircon crystals are characterized by extreme short prisms as being more or less equidimentional and exhibiting square cross sections. Sometimes, it shows oscillatory zoning and develops radiating cracks in the
Table 5 : EDX analysis of samarskite

\begin{tabular}{lllllllllllll}
\hline Element & Nb & Ta & Ti & Fe & U & Th & Ca & Y & Ce & Na \\
\hline Wt\% & 44.6 & 5.97 & 2.4 & 12.5 & 8.65 & 5.3 & 4.35 & 2.4 & 1.17 & 2.66 \\
\hline
\end{tabular}

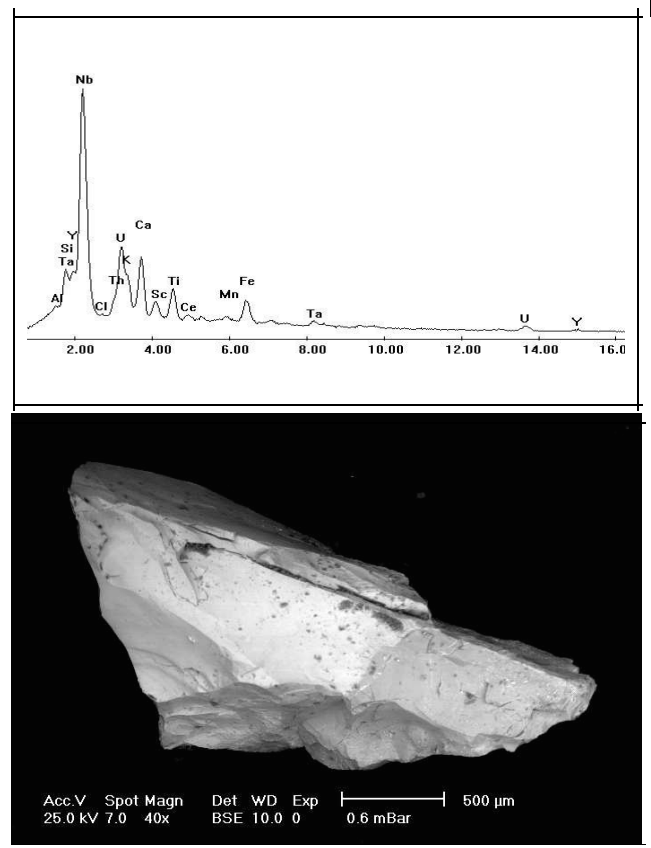

Fig.14: EDX and BSE image of samarskite

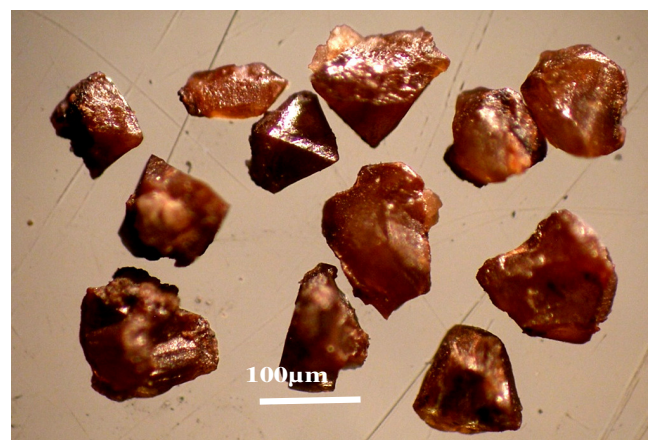

Fig.15: Stereophotograph showing metamict zircon grains 
surrounding biotite or quartz. In thin sections, it is included in biotite and quartz showing its characteristic radioactive pleochroic haloes. The radioactive crystals of zircon are zoned and show metamictization. Abdalla et al. (2008) stated that radioactive zircons are usually zoned and are characterized by metamictization. The EDX analysis confirmed that the studied zircon is mainly composed of $\mathrm{ZrO}_{2}$ (62.1 wt \%), $\mathrm{SiO}_{2}(31.8 \mathrm{wt} \%),(4.5 \mathrm{wt} \%)$ of $\mathrm{UO}_{2}$ and $\left(1.3 \mathrm{wt} \%\right.$ ) of $\mathrm{ThO}_{2}$ (Fig. 16).

\section{Allanite CaREEAl ${ }_{2} \mathrm{Fe}^{2+}\left(\mathrm{SiO}_{4}\right)_{3} \mathrm{OH}$,}

Allanite is the most abundant rare earth element bearing mineral of the epidote group (Armbruster et al., 2006). Allanite is a common accessory mineral in many granitic rocks and pegmatites. Magmatic allanite shows strong preference for light rare earth elements over heavy rare earth elements (Giere and Sorensen, 2004). Due to the presence of radioactive elements (U\&Th), partial metamictization of allanite is a common phenomenon. The International Mineralogical Association lists three minerals in the allanite group, each recognized as a unique mineral, allanite-(Ce), allanite(La), and allanite-(Y), depending on the dominant rare earth element present. Allanite, also called orthite, contains up to $20 \%$ REE and is a valuable source of them. The study allanite occurs as brown subhedral to euhedral prismatic crystals (Fig. 17). The study allanite is associated with biotite. Analytical results by ESEM (Fig. 18) show that the structure of allanite is strongly selective for LREE, where cerium (Ce) (14 wt \%) predominates over all other REE, and therefore the examined mineral corresponds to allanite-(Ce) (Wood and Ricketts, 2000). Also, EDX shows that the study allanite-(Ce) contains Th (17 wt \%), U ( $2 \mathrm{wt} \%)$, as well as high contents of $\mathrm{La}(6.2 \mathrm{wt}$ $\%), \operatorname{Sm}(3.02$ wt \%), Eu (3.31 wt \%) and Gd $(3.14 \mathrm{wt} \%)$ (Table,6). Due to their similarity to the rare earth elements in ionic radius, uranium and thorium may be incorporated in the structure of allanite.
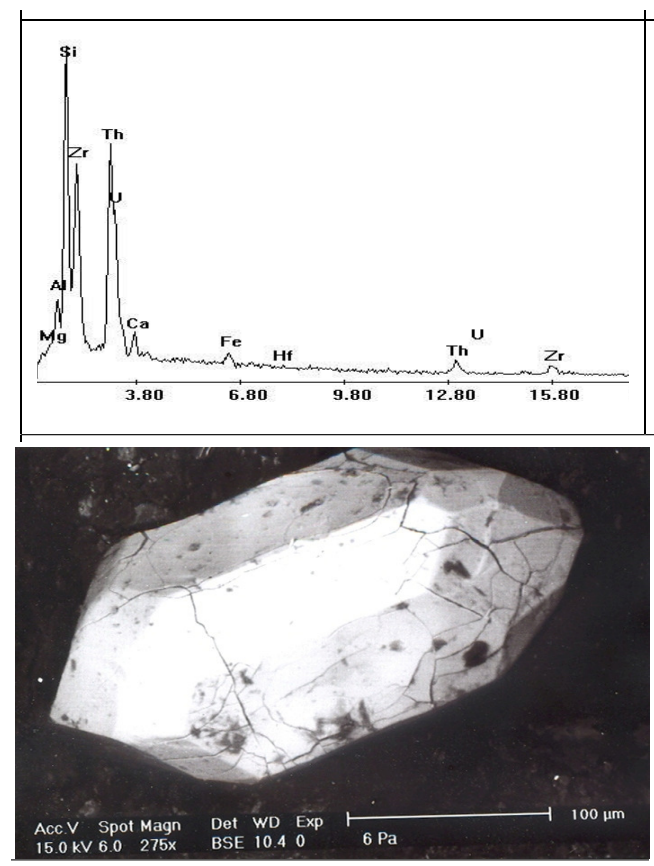

Fig.16: EDX and BSE image of metamict zircon

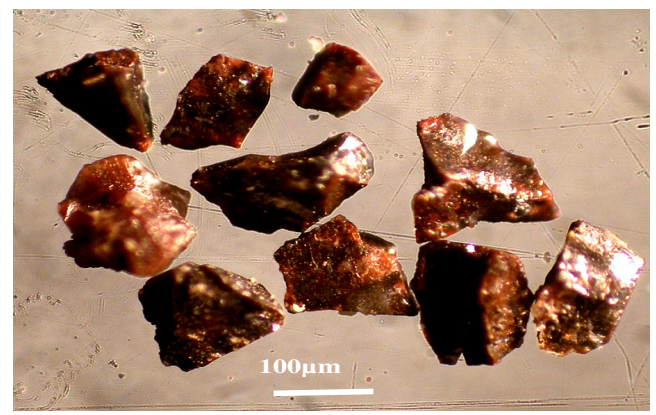

Fig.17: Stereophotograph showing metamict brown colored grains of allanite

Table 6 : EDX analysis of allanite

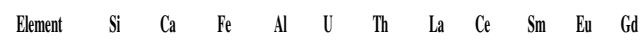

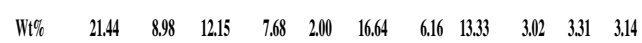




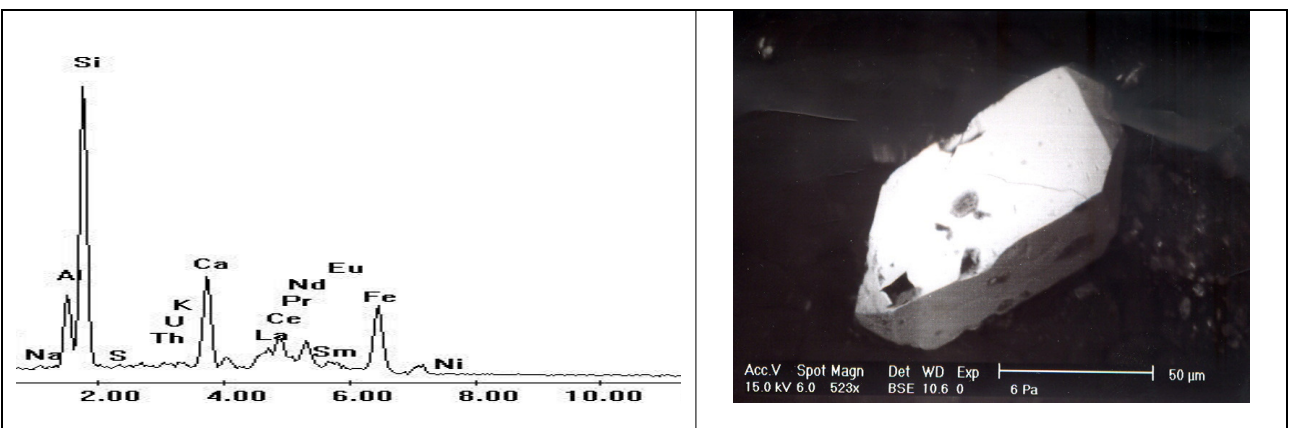

Fig.18: EDX and BSE image of Allanite

\section{Fluorite}

Fluorite is usually formed during late magmatic crystallization of alkaline and peralkaline granites occurring as disseminations or as late-crystallizing hydrothermal deposits (Deer et al., 1992). It is widely distributed among the basement rocks especially the younger granites and some related veins and pegmatite bodies. It occurs as cubic crystals of different colors such as white, yellow, green, pink, blue, violet and black. Many authors attributed the cause of these different colors of fluorite to different reasons such as presence of inorganic impurities, effect of radioactivity, heat and pressure. The studied fluorite occurs as violet colored euhedral to subhedral crystals. The composition is confirmed by EDX analysis showing fluorite contains $\mathrm{UO}_{2}$ in addition to the main constituting ions of fluorite as F and Ca (Fig. 19). El-Mansi (2000) suggested that the blue and violet varieties of fluorite are rich in $\mathrm{U}$ and $\mathrm{Th}$.

\section{DISCUSSION AND CONCLUSION}

The studied monzogranites and alkalifeldspar granites occur as small mass intruding the granodiorites. The monzogranites represent the bulk of the pluton and intruded by the alkali-feldspar granites forming a small mass or cupola at the roof of the monzogranites. The alkali-feldspar granites cut

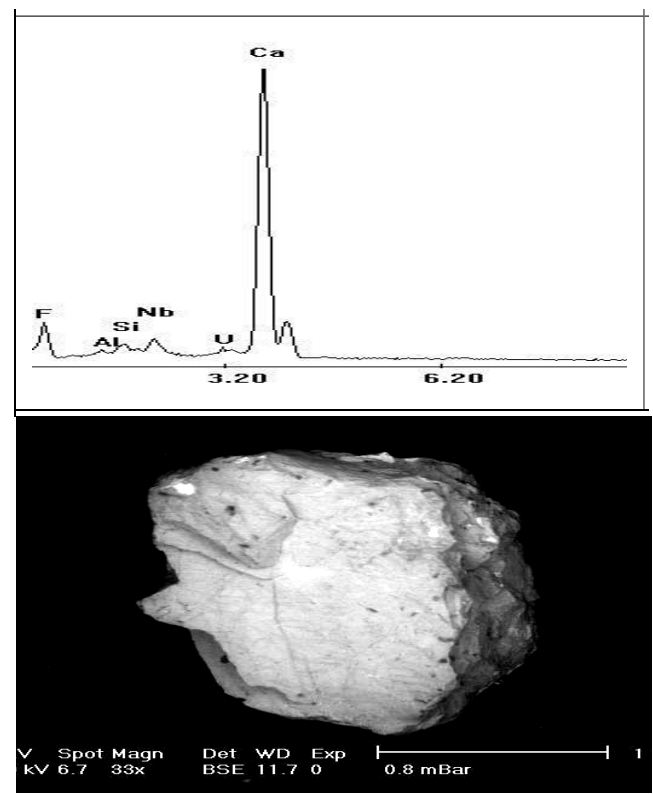

Fig.19: EDX and BSE image of Violet fluorite

by faults trending in different directions and show brecciation and local silicification, hematitization, sericitization and chloritization.

Secondary processes such as sericitization of K-feldspars, sussuritization of plagioclase and chloritization of biotite are the result of late hydrothermal activity. Crystal deformation is supported by the wavy ex- 
tinction and recrystallization of quartz, kink biotite and plagioclase, joints and faults which are a likely response to post emplacement stresses imposed on the studied granites. The fractures facilitate the circulation of hydrothermal fluids, leading to mobilization and redistribution of radioactive elements. Also, the presence of fluorite associating the mineralization indicates that the hydrothermal alteration processes were involved during the formation of the radioactive minerals.

Chondrite-normalized REE patterns show that the alkali-feldspar granites have higher REE content (average $\mathrm{REE}=202 \mathrm{ppm}$ ) than the monzogranites (average $\mathrm{REE}=43 \mathrm{ppm}$ ) and the alkali-feldspar granites display an almost flat REE pattern with strong negative Eu-anomaly suggesting that the alkali-feldspar granites are formed from more evolved magma (Singh and Vallinayagam, 2012 and Mckeough et al., 2013).

The average concentration of $U$ and $T h$ of the studied alkali-feldspar granites is 73 and $119 \mathrm{ppm}$, respectively being significantly higher than twice the Clark value. The enrichment of alkali-feldspar granites in U (73 $\mathrm{ppm})$ and $\mathrm{Th}(119 \mathrm{ppm})$ considered them as uraniferous granites.

Detailed mineralogical studies for the radioactive alkali-feldspar granite samples revealed the presence of some radioactive minerals such as thorite, uranophane, samarskite, allanite, metamict zircon and violet fluorite.

The studied allanite is a REE-rich epidote via the coupled substitution $\mathrm{REE}^{3+}+\mathrm{Fe}^{2+}$ $\leftrightarrow \mathrm{Ca}^{2+}+\mathrm{Fe}^{3+}$. It is very rich in $\mathrm{Ce}$ and can be designated as allanite -Ce. Also, it contains more Th than $\mathrm{U}$, because Th usually incorporated at the expense of the REE via the coupled substitution $\mathrm{Th}^{4+}+\mathrm{Ca}^{2+} \leftrightarrow 2 \mathrm{REE}^{3+}$. The EDX data show a distinct enrichment of LREE compared with HREE, this is comparable to data reported from other igneous allanite.

The concentrations of Th in the studied zir- con are much lower than those of $\mathrm{U}$, which is in accord of the general preference of the zircon structure for smaller U (Hoskin and Schaltegger, 2003).

\section{REFERENCES}

Abdalla, H. M., 1996. Geochemical and mineralogical studies at Um Ara rare metals prospect South Eastern Desert, Egypt. Ph. D. Thesis, Hokkaido Univ., Japan, 232p.

Abdalla, H. M.; Helba, H., and Matsueda, H., 2008. Chemistry of zircon in rare metal granitoids and associated rocks, Eastern Desert, Egypt. Resource Geology, 59(1), 51-68.

Abu Deif, A., and El-Tahir, M., 2008. A new uranium occurrence, Gabal El-Missikat prospect, Central Eastern Desert, Egypt. JKAU: Earth Sci.,19, 85-97.

Abu Deif, A. A.; El-Husseiny, M. O.; El-Balakssy, S. S., and Abu Zeid, E. K., 2007. Wall rock alteration and uranium mineralization at $\mathrm{M}$ III uranium occurrence, Gabal El-Missikat younger granites, Central Eastern Desert, Egypt. 2nd Intern. Conf. Geol. Tethys, Fac. Sci., Cairo Univ. Egypt, 647-654.

Abu Zeid, E. K., 2006. Geology, petrogenesis and radioactivity of selected pegmatitic bodies from the Eastern Desert and South Sinai, Egypt. Ph. D. Thesis, Ain Shams Univ, 243p.

Ahmed, F. Y., and Dardier, A. M., 1999. Geology, geochemistry and U-Th distribution in Um Iffayn granitic pluton, Eastern Desert, Egypt. Ann. J. Geol. Egypt, 22, 265-286.

Anders, E., and Grevesse, N., 1989. Abundances of the elements: Meteoritic and Solar. Geochimica et Cosmochimica Acta, 53, 197-214.

Armbruster, T.; Bonazzi, P.; Akasaka M.; Bermanec, V.; Chopin, C.; Giere, R.; Heuss-Assbicher, S.; Liebscher, A.; Menchetti, S., and Pan, Y. and Pasero, M., 2006. Recommended nomenclature of epidote-group minerals. European J. Mineralogy, 18, 551-567.

Assaf, H. S.; Mahdy, M. A., and El Afandy, A. H., 
1997. Egyptian younger granites, an approach to define parameters favoring formation of uranium deposits. 3rd Conf. Geochemistry, Alexandria Univ., 409-420.

Banks, D. A.; Yardly, B. W.; Campbell, A. R., and Jarvis, K. E., 1994. REE composition of an aqueous magmatic fluid: A fluid inclusion study from the Capitain pluton, New Mexico. Chem. Geol.,113, 259-272.

Cathelineau, M., 1987. U-Th rare earth elements mobility during albitization and quartz dissolution in granitoids: Evidence from South East French Massif Central. Bull. Mineral.,101, 249-259.

Cesbron, F., 1993. New mineralogical data on uranophane and $\beta$-uranophane; Synthesis of uranophane. Mineralogical Magazine, 57, 301-308.

Cuney, M., and Friedrich, M., 1987. Physicochemical and crystal-chemical controls on accessory mineral paragenesis in granitoids: Implications for uranium metallogenesis, Bull. Mineral.,110, 235-247.

Dawood, Y. H., and Abd El-Naby, H. H., 2001. Mineralogy and genesis of secondary uranium deposits, Um Ara area, South Eastern Desert, Egypt. J. Afri. Earth Sciences, 32(2), 317-323.

Darnely, A. G., 1982. Hot granites. Some general remarks in uranium in granites. In: geological Survey of Canada (Maurice, Y. T., Ed.). Paper 81-23,1-10.

Deer, W. A.; Howie, R. A., and Zussman, J., 1992. An introduction to the rock-forming minerals. Low price edition, ELBS, Longman, 528p.

El Gaby, S., 1975. Petrochemistry of some granites from Egypt, N. Jb. Miner. Abh, 124, 147-189.

El-Kammar, A. M.; Salman, A. E.; Shalaby, M. H., and Mahdy, A. I., 2001. Geochemical and genetical constraints on rare metals mineralization at the central Eastern Desert of Egypt. Geochemical J., 35, 117-135.

El Kholy, D. M.; El-Husseiny, M. O.; Saleh, W. H., and El Zalaky, M. A., 2012. Remote sensing,
Geology and geochemistry on the GVIII uranium mineralization, Gabal Gattar, North Eastern Desert, Egypt. Nuclear Sciences Scientific J., 1, 69-84.

El-Mansi, M. M., 2000. Colouration of fluorite and its relation to radioactivity. Egypt. Mineral.,12, 93-106.

El-Ramly, M. F., and Akaad, M. K., 1960. The basement complex in the central Eastern Desert of Egypt between lat. $24^{\circ} 30^{\prime}$ and $25^{\circ} 40^{\prime}$. Geol. Surv. Egypt, paper no. 8, 15p.

Förster, H. J., 2006. Composition and origin of intermediate solid solutions in the system thoritexenotime-zircon-coffinite. Lithos, 88, 35-55.

Giere, R., and Sorensen, S. S., 2004. Allanite and other REE-rich epidote-group minerals. In: Epidotes(Liebscher, A. \& Franz, G. ,Eds). Reviews in Mineralogy and Geochemistry , 56, 431-493.

Hanson, S. L.; Simmons, W. B.; Falster, A. U.; Foord, E. E., and Lichte, F. E., 1999. Proposed nomenclature for samarskite-group minerals: new data on ishikawaite and calciosamarskite. Mineralogical Mag., 63(1), 27-36.

Hassan, M. A., and Hashad, A. H., 1990. Precambrian of Egypt. In: The Geology of Egypt (Said, R. , Ed.). Balkema, Rotterdam, Netherlands, 201-245.

Hoskin, P. W. O., and Schaltegger, U., 2003. The composition of zircon and igneous and metamorphic petrogenesis. Rev. Mineral. Geochem., 53, 27-62.

Hume, W. F., 1935. Geology of Egypt, part II, The later plutonic and minor intrusive rocks. Geol. Surv. Egypt, 286.

Hussein, A. A.; Ali, M. M., and El Ramly., M. F., 1982. A proposed new classification of the granites of Egypt. J. Volcan. Geother. Res., 14, 187-198.

Kennedy, W. Q., 1964. The structural differentiation of Africa in the Pan-African (500 m.y.) tectonic episode; Research Institute of African Geology, 
Leeds Univ., 8th Ann. Report, 48-49.

Lei, X.; Rucheng, W.; Xiaoming, C.; Jiansheng, Q., and Dezi, W., 2005. Th-rich zircon from peralkaline A-type granite: Mineralogical features and petrological implications. Chinese Science Bull., 50(8), 809-817.

Mckeough, M. A.; Lentz, D. R.; Mcfarlane, Ch. R. M., and Brown, J., 2013. Geology and evolution of pegmatite-hosted U-Th - REE-Y-Nb mineralization, Kulyk, Eagle and Karin lakes region, Wollaston Domain, northern Saskatchewan, Canada: examples of the dual role of extreme fractionation and hybridization processes. J. Geosciences, 58, 321-346.

Miller, C. F., and Mittlefehldt, D. W., 1982. Depletion of light rare earth elements in felsic magma. Geology, 10, 129-133.

Mohamed, F. H.; Hassanen, M. A.; Matheis, G., and Shalaby, M. H., 1994. Geochemistry of the Wadi Hawashia granite complex, North Egyptian Shield. J. Afri. Earth Science, 19 (1), 6174.

Moussa, E. M., 1998. Geochronological studies of some granitoids; application to geochemical evolution and tectonic history of the Northern Eastern Desert, Egypt. Ph. D. Thesis, Ain Shams Univ., 284p.

Moussa, E. M. M.; Stern, R. J.; Manton, W. I., and Ali, K. A., 2008. SHRIMP zircon dating and $\mathrm{Sm} / \mathrm{Nd}$ isotopic investigations of Neoproterozoic granitoids, Eastern Desert, Egypt. Precambrian Research, 160, 341-356.
Rankama, K., and Sahama, T. G., 1955. Geochemistry. Chicago Univ. Press. Chicago, 37p.

Shalaby, M. H., 1995. New occurrence of uranium mineralizations G-VII, Gabal Gattar uranium prospect, North Eastern Desert, Egypt. Bull. Fac. Sci. Alex. Univ., 35, 447-460.

Shalaby, M. H.; Bishta, A. Z.; Roz, M. E., and El Zalaky, M. A., 2010. Integration of geologic and remote sensing studies for the discovery of uranium mineralization in some granite plutons, Eastern Desert, Egypt, JAKU, Earth Science, 21(1), 1-25.

Singh, L. G., and Vallinayagam, G., 2012. Petrological and geochemical constraints in the origin and associated mineralization of A-type granite suite of the Dhiran area, Northwestern Peninsular India. Geosciences, 2(4), 66-80.

Singh, A. K.; Singh, R. K. B., and Vallinayagam, G., 2006. An orogenic acid volcanic rocks in the Kundal area of the Malani igneous suite, North western India: Geochemical and petrogenetic studies. J. Asian Earth Sciences, 27, 544-557.

Streckeisen, A. L., 1976. To each plutonic rock its proper name. Earth Sci. Rev., 12, 1-33.

Whalen, J. B.; Currie, K. L., and Chappell, B. W., 1987. A-type granites: Geochemical characteristics, discrimination and petrogenesis. Contrib. Mineral. Petrol., 95, 407-419.

Wood, S. A., and Ricketts, A., 2000. Allanite-(Ce) from the Eocene Casto granite, Idaho: Response to hydrothermal alteration. Canad. Mineral., $38,81-100$.

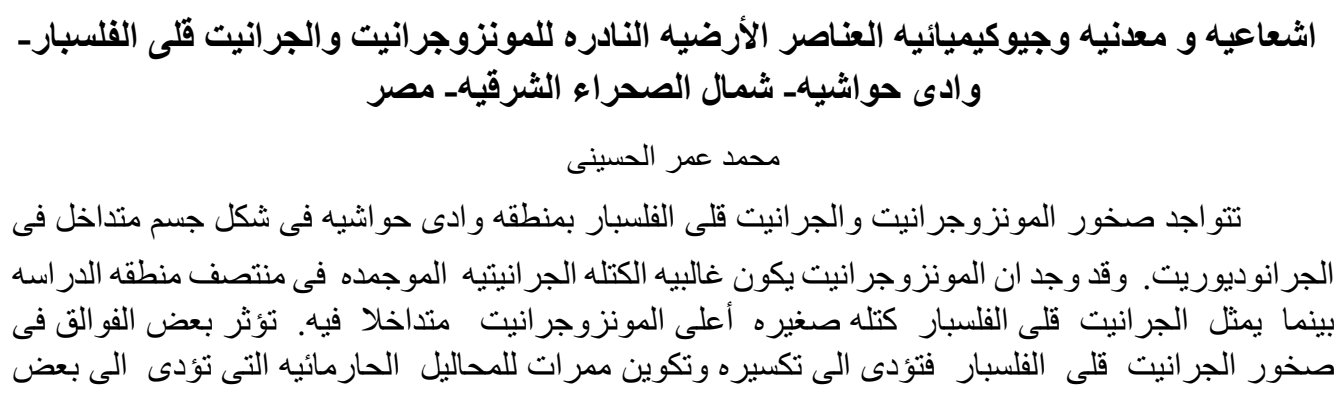


عمليات التحول الثانويه مثل عilisification, hematitization, sericitization and chloritization.

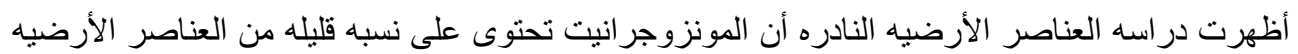

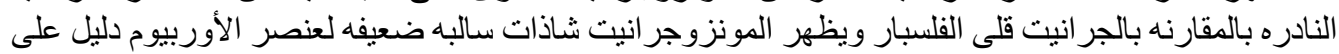

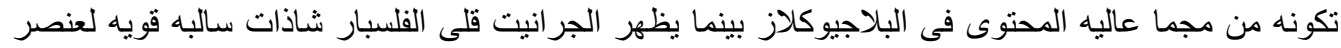

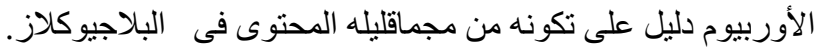

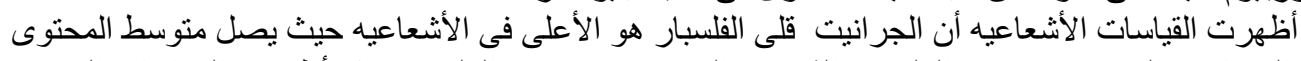

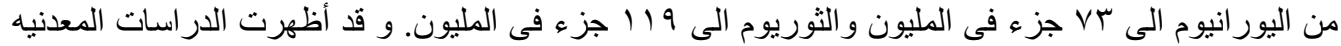

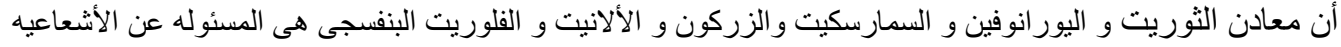

